https://nv.nltu.edu.ua

https://doi.org/10.36930/40300121

Article received 05.02.2020 p.

Article accepted $27.02 .2020 \mathrm{p}$.

$@ \bowtie$ Correspondence author UDK 331.446 .3

N. S. Kazmiruk

kazmiruk2277@gmail.com

О. В. Станіславчук, В. М. Марич, Н. С. Казмірук

Львівський державний університет безпеки життєдіяльності, м. Львів, Украйна

\title{
АКТУАЛЬНІ ПИТАННЯ ЗАБЕЗПЕЧЕННЯ БЕЗПЕКИ ПРАЦІ ШУЛЬГИ
}

Встановлено, що незважаючи на те, що частка шульг у світі й в Україні зокрема, в наш час зростає, дослідження шляхів адаптації таких людей у суспільному житті обмежується тільки віковою категорією малюки та школярі. З'ясовано, що проблему забезпечення безпеки праці ліворуких людей в Україні не досліджують, а тому такі працівники потерпають від непристосованості умов праці та організації робочого місця відповідно до їхніх фізіологічних потреб. Виявлено, що промисловість у нашій країні і у більшості інших країн не виготовляє технологічного обладнання та інструменту, адаптованого до роботи на ньому робітників-шульг. Виконання роботи ліворукими працівниками засобами праці, що передбачені для праворуких, знижує продуктивність праці та якість виконаної роботи, підвищує рівень ризику виникнення виробничого травматизму та розвитку професійних захворювань. Охарактеризовано основні проблеми, які виникають під час професійної діяльності робітника-шульги у різних галузях промисловості, а також виявлено окремі випадки та види робіт, для виконання яких перевагу необхідно надати саме робітнику-шульзі для підвищення ефективності та безпеки праці. Розглянуто умови праці верстатника меблевої фабрики, шкідливі і небезпечні виробничі чинники, що впливають на його життя і здоров'я та запропоновано загальні рекомендації щодо підвищення безпеки праці верстатників-шульг. Встановлено актуальність подальших досліджень із вирішення проблеми адаптації умов праці до потреб ліворуких працівників у різних галузях промисловості.

Ключові слова: ліворукий працівник; праворукий працівник; умови праці; робоче місце; інструмент; виробничий травматизм.

Вступ. Проблема створення безпечних і нешкідливих умов праці хвилювала людство завжди. Охорона праці у своєму розвитку пройшла великий історичний шлях, набираючи інтенсивного руху з початком розквіту технічного прогресу. Проте машинне виробництво та механізація й автоматизація виробничих процесів разом із полегшенням праці та підвищенням іiї продуктивності потребують вищого рівня професійних знань і навичок, висувають вимоги до швидкості та якості роботи органів чуття та психічних властивостей працівника i, попри це, несуть в собі небезпеку для життя та здоров'я працівників.

Актуальність дослідження. В Україні останнім часом приділяють велику увагу створенню безпечних і нешкідливих умов праці для людей з інвалідністю [6, 7]. Щодо такої категорії людей, як шульга, то всі дослідження стосуються тільки їх адаптації у суспільстві у період малюкового та шкільного віку $[1,4,8]$. Облаштування ж робочого місця працівника-шульги, відповідно до його фізіологічних та психологічних особливостей, покладається на нього самого. А це не завжди $\epsilon$ можливим, особливо у разі застосування інструменту чи обладнання, розрахованого на праворукого працівника.

Постановка завдання дослідження. Останніми рока- ми в Україні активно розвивається меблева промисловість, і кількість меблевих фабрик на вітчизняному ринку зростає швидкими темпами. Зазвичай це сучасні підприємства, оснащені новітнім обладнанням. Враховуючи, що ліворуких у світі нараховується 10-17 \%, питання створення безпечних і нешкідливих умов праці для таких людей на меблевій фабриці $є$ актуальним питанням.

Об'єкт дослідження - особливості та потреби працівників-шульг і основні складники робочого місця та вимоги щодо його організації.

Предмет дослідження - адаптація робітників-шульг до умов виробничого середовища та створення комфортних умов праці для цієї категорії працівників.

Мета дослідження - вивчити особливості умов праці ліворуких працівників та сформувати рекомендації щодо зниження ймовірності виробничого травматизму серед верстатників-шульг на меблевій фабриці.

Для досягнення поставленої мети потрібно виконати такі основні завдання дослідження:

• проаналізувати проблеми, які виникають у працівниківшульг під час професійної діяльності у різних галузях промисловості;

• виявити випадки, коли для виконання робочих завдань пріоритет варто надавати робітнику-шульзі;

Інформація про авторів:

Станіславчук Оксана Володимирівна, канд. техн. наук, доцент, кафедра промислової безпеки та охорони праці. Email: stok_oven@ukr.net; https://orcid.org/0000-0001-5784-005X

Марич Володимир Михайлович, канд. техн. наук, доцент, кафедра промислової безпеки та охорони праці. Email: stok_oven@ukr.net; https://orcid.org/0000-0001-7051-4494

Казмірук Наталія Станіславівна, студент, кафедра промислової безпеки та охорони праці. Email: kazmiruk2277@gmail.com; https://orcid.org/0000-0002-6771-2446

Цитування за ДСТУ: Станіславчук О. В., Марич В. М., Казмірук Н. С. Актуальні питання забезпечення безпеки праці шульги. Науковий вісник НЛтУ України. 2020, т. 30, № 1. С. 121-126.

Citation APA: Stanislavchuk, O. V., Marych, V. M., \& Kazmiruk, N. S. (2020). Actual issues for providing labor safety of left-handed workers. Scientific Bulletin of UNFU, 30(1), 121-126. https://doi.org/10.36930/40300121 
• окреслити поняття робочого місця, його складників, а також основних вимог щодо його організації відповідно до фізіологічних та психологічних властивостей працівника;

- розробити рекомендацій щодо створення сприятливих умов праці для працівника-шульги на робочому місці верстатника для зниження ймовірності виробничого травматизму на меблевій фабриці.

Матеріал $і$ методи дослідження. Під час проведення досліджень використано дані літературних джерел та результати виконаного обстеження робочих місць верстатників у КТ "Радивилівська меблева фабрика", а також такі методи дослідження: монографічний, експертних оцінок, аналізу, синтезу та індукції.

Наукова новизна дослідження та практична значуuість отриманих результатів. Тема дослідження полягає у вивченні нагальних проблем, які виникають у працівників-шульг під час їх виробничої діяльності, а також шляхам вирішення цієї проблеми. Це дасть змогу раціонально використовувати працю ліворуких робітників, а також облаштовувати для них ергономічні робочі місця та створювати сприятливі умови праці, внаслідок чого знизиться ризик розвитку професійних захворювань та випадків виробничого травматизму, а також підвищиться продуктивність праці шульг.

Викладення основного матеріалу. За кілька останніх десятиліть через припинення переучування шульг, кількість ліворуких людей у світі зросла у 3-4 рази. Певний досвід зарубіжних країн [3, 10] показав, що дбайливе ставлення до ліворуких дітей сприятливо позначається на їх подальшому розвитку, а відповідно, й на успіхах суспільства загалом. За статистикою, 50 \% всіх людей $\epsilon$ прихованими шульгами, тобто домінуючою рукою у них є права, проте в екстрених ситуаціях ліва може взяти головну роль [2].

Ліворукість може передаватися спадково або розвиватись через травми або хвороби. Дуже часто у звичайних сім'ях народжуються ліворукі діти внаслідок стресу під час пологів, затяжного процесу народження дитини чи, навіть, асфіксії.

Збільшення частки ліворукого населення в наш час можна пов'язати $з$ тим, що постійно зростає частка роботи, пов'язана не 3 фізичними зусиллями, а з творчістю і мисленням, за яке відповідає права півкуля мозку (вона ж відповідає за ліву руку). Існує думка, що є певна перевага ліворуких над праворукими у спорті, музиці та інших творчих галузях. Шульги ефективніше використовують обидві півкулі мозку. Саме тому вони стають швидшими і спритнішими у навчанні. Стверджують, що шульги талановитіші в орієнтуванні у просторі, математиці, мистецтві та архітектурі. Серед ліворуких багато нобелівських лауреатів, письменників та митців, а праворукі більш обдаровані у вербальних навичках.

За кордоном ліворуким особам приділяють більшу увагу, ніж в Україні. Наприклад, у закладі харчування запитують, чи людина праворука чи шульга, щоб правильно розкласти столове приладдя. На підприємствах під час прийому на роботу також цікавляться цим питанням, щоб зручніше облаштувати робоче місце.

В Україні під час прийому людини на роботу не запитують про ведучу руку працівника, оскільки не усвідомлюють, що за усіх інших позитивних характеристик претендента на роботу, у ліворуких продуктивність праці на обладнанні для праворуких буде нижчою, не говорячи вже про дискомфортні умови праці, потен- ційну небезпеку для здоров'я та життя працівникашульги.

На сьогодні у світі частка ліворуких становить 1017 \% населення. 3 часом і віком їх стає дедалі менше, адже хтось перевчається, хтось пристосовується до праворукого світу. Серед 20-річних нараховують $13 \%$ шульг, серед 80-річних - менше одного відсотка. В Україні, як стверджують експерти, виросло перше покоління ліворуких людей. Це ті люди, яких не перевчали в дитячих садочках та в школі до писання правою рукою. А вчителі, своєю чергою, зазначають, що у школах 3 кожним роком кількість таких дітей, що пишуть лівою рукою, постійно зростає. Професор кафедри дитячої, соціальної та судової психіатрії Національної академії післядипломної освіти ім. П. Шупика Анатолій Чуприков зазначив, що раніше в Україні нараховувалось від 3 до 3,5 \% шульг, а вже на сьогодні - 10-12 \% людей $[9,11]$.

Але сучасний світ створений для людей, які все роблять правою рукою, починаючи від турнікетів у метро, банкоматів та терміналів, кухонного, письмового приладдя, замків, дверей, ручок для підписування в офісах (прикріплених шнурівкою із правого боку), комп'ютерних мишок, планшетів і телефонів, давачів для прикладення ключа в установах, верстатів на виробництві аж до застосування новітніх комп'ютерних технологій у різних галузях, зокрема, у медицині та автомобілебудуванні.

Фахівці стверджують, що у ліворуких за кермом автомобіля дещо повільніша реакція, ніж у праворуких, оскільки вони звикли всі основні операції виконувати лівою рукою. Тому для таких людей зручнішим є автомобіль 3 лівим розташуванням керма або 3 автоматичною коробкою передач.

Існують певні проблеми й у кухаря-шульги, у якого розміщення усього необхідного під рукою має бути 3 протилежного боку, ніж у праворукого працівника. Спричиняють дискомфорт дошки для нарізання 3 ручкою збоку, адже шульга нарізає не зліва вправо. Істотно уповільнюють роботу кухаря мірні кружки, соусні ложки, ручні міксери, м'ясорубки та подрібнювачі.

Маркетингові методи також розраховані на праворуких. Так, наприклад, в усіх супермаркетах рух по території торгівельної зали організовано проти годинникової стрілки для того, щоб праворуким покупцям було зручніше складати товар у кошик, що підвищуватиме показник продаж. Спортивні стадіони облаштовані за таким самим принципом: рух спортсменів стадіоном відбувається проти годинникової стрілки, щоб на поворотах активна права нога могла запобігти падінню.

Щоб зменшити проблему адаптації до існування у сучасному життєвому середовищі ліворуких людей i привернути до них увагу виробників товарів і різноманітного устаткування, у світі почали відзначати Міжнародний день шульги. Це свято було започатковано 13 серпня 1976 р. Ширше його стали відзначати у 1992 р. $з$ ініціативи британського Клубу ліворуких.

Зазвичай товари для шульг, які почали виготовляти (майже усі за кордоном), зроблені за методом дзеркального відображення. У продажу є годинники, які мають дзеркальне відображення, а стрілки рухаються в інший бік, щоб краще шульгам сприймати зображення. Також випускають книги, зошити, журнали, блокноти, які мають перепліт з протилежного від звичного боку. Промисловість випускає: кулькові ручки із зігнутим стер- 
жнем або швидкосохнучим чорнилом, для того, щоб не стирати щойно написаний лівою рукою текст; олівці за спеціальним грифелем, що не стирається. Створені спеціальні тренувальні дошки для дітей, на яких навчають писати алфавіт. Ще $\epsilon$ гаманець, штопор, лінійка з нумерацією у зворотному напрямку, ножі, ножиці і точило для олівців, а також різні види музичних інструментів, наприклад, гітара для гри лівою рукою. Її гриф "дивиться" в інший бік, а струни розташовані у зворотній послідовності. Деякі ліворукі люди встановлюють собі двеpi та вікна в зручний для їхнього користування бік. У Тулі почали випускати зброю для шульг.

Ще одним кроком назустріч ліворуким є розроблення та виготовлення швейної машинки, яка до недавнього часу була тільки для праворуких. Проте таку машинку шульги можуть придбати тільки для домашнього користування за спеціальним замовленням.

Для працівників, що працюють з ЕОМ, промисловість за кордоном почала виготовляти клавіатури та мишки для ліворуких, а також офісні меблі. Проте в Україну їх завозять мало і тільки останніх моделей, тому коштують вони дорого і шульги рятуються самі: змінюють функції клавіш на комп'ютерних мишах, клавіатуру ж змінити практично неможливо.

Спеціалізованими манікюрними інструментами рекомендують користуватися майстрам-шульгам манікюру. Адже працюючи на обладнанні для праворуких, майстер-шульга здійснює неприродні рухи, внаслідок чого може виникнути нервовий або м'язовий стрес. Це не так помітно на початку професійної діяльності, проте за великої кількості клієнтів може спричинити проблеми зі здоров'ям. Зараз закордонна промисловість випускає спеціальні серії манікюрних інструментів для майстрів-шульг: лівобічні ножиці, лопатки, фрези, кусачки. Робоче місце майстра-шульги також облаштовується дзеркально до того, як це робить праворукий майстер.

Зарубіжна промисловість пішла назустріч і лікарямстоматологам, випускаючи стоматологічні установки, які $є$ не тільки компактними, а й можуть трансформуватися як під праворукого, так і під ліворукого лікаря. Передбачена можливість комфортного розташування усіх інструментів, підносів, системи слиновідсмоктування та плювальниці під рукою.

Якщо вдома або в офісі людині-шульзі ще простіше пристосуватися до довколишніх предметів для праворуких, то на виробництві проблему неможливо вирішити розвернувши верстат в інший бік. У цьому разі працівник підлаштовується під роботу з такими інструментами, на що потрібен час, проте неприродність рухів призводить до травм та захворювань.

Окрім цього, є певні види робіт, які потребують високої точності рухів, яка може бути втрачена через швидку стомлюваність внаслідок виконання неергономічних робочих рухів. Наприклад, це стосується робіт металургів, електромеханіків підземних шахт тощо. Складними у виконанні є для шульг такі роботи, як закручування саморізу (необхідно робити рухи кистю назовні, а це важче, ніж рухи усередину праворукому). Особливі навички необхідно мати шульзі під час роботи 3 болгаркою, без яких людина може завдати собі травмувань. Місця, зручні для забивання цвяха або закручування гайки чи вентиля-гайки для праворукої людини, зумовлюють труднощі у шульг.
За столом шульга має сидіти з лівого боку, в іншому разі він буде заважати роботі правої руки сусіда. Освітлення робочого місця ліворукої людини має забезпечуватися з правого боку.

Важливо зважати під час приймання на роботу шульг, чи їх професійна діяльність буде пов'язана із застосуванням інструментів, передбачених для праворуких і до яких шульгам дуже тяжко користуватися. Наприклад, це: ножиці, консервний ніж старої моделі, майже всі сучасні будівельні та слюсарні інструменти (пили, ножі, дрилі) тощо. Також, через переважання праворуких робітників, більшість станків та агрегатів проектують без урахування можливостей шульг. Якщо такий працівник за певний час і навчився працювати правою рукою, то в екстремальних ситуаціях він рефлекторно прагне застосувати свою ведучу руку, що може стати причиною аварії або травми. Наприклад, якщо кнопка екстреної зупинки станка чи верстата буде встановлена для праворукого працівника, то шульга може просто в такій ситуації не зорієнтуватися. Зрозуміло, що шульга не загине від того, що користується комп'ютерною мишкою для праворуких, але якщо йдеться про керування автомобілем, роботу з бензопилою або іншим небезпечним робочим інструментом, то це може загрожувати як здоров'ю, так і життю людини-шульги.

Проте в деяких випадках ліворукий працівник опиняється у сприятливіших для нього умовах виконання роботи, ніж праворукий. Наприклад, коли необхідно затягнути гайку, до якої неможливо досягнути з правого боку (біля стіни чи труби), це зручно зробити лівою рукою. Доречною ліворукість виявляється у зварювальників під час зварювання трубопроводів, прокладених у кар'єрі у важкодоступних місцях або проведених попід стелею чи у вузькій траншеї. Також ліворукому зварювальнику зручніше виконувати зварювальні роботи ходових конструкцій та ковшів екскаваторів тощо.

Зручним для роботи ліворуких робітників $\epsilon$ токарний станок, адже всі органи керування розташовані ліворуч. Токарю шульзі немає потреби обертатися усім корпусом, щоб перемкнути швидкість чи подавання, увімкнути чи вимкнути обертання шпинделя, достатньо лише зробити необхідний рух рукою. Йому зручніше стояти, коли лівою рукою зміщує поперечний супорт, на якому закріплений різець, а правою пересуває поздовжній. У цьому випадку не заважає стружка і видимість $\epsilon$ кращою. Також зручніше шульзі робити вимірювання розмірів деталі штангельциркулем, оскільки світло падає на шкалу і зручніше утримувати деталь.

Окрім цього, варто зауважити, що ліворукі працівники краще можуть застосовувати обидві руки, пристосовуючись до умов праці, обладнання та інструменту, ніж праворукі.

Наведені приклади наштовхують на думку, що варто вивчати подібні до наведених приклади, коли доцільніше застосовувати працю шульг та використовувати їх у практичній діяльності.

Деревообробна галузь є важливою і невід'ємною складовою частиною для нашого повсякденного життя та суспільства загалом. Людина не може обійтись без меблевої продукції, яка виконує різні функції і забезпечує загальноприйняті умови людського життя. Меблева промисловість займає значне місце в економіці країни надаючи немалий прибуток. Велика кількість трудових ресурсів зайнята саме на виробництвах цієї галузі [5, 12], зменшуючи безробіття. 
На сьогодні Україна є однією з найбільших виробників меблевої продукції, а саме корпусних меблів. До них відносять: побутові й офісні столи, стінки і шафи, кухні, полиці, а також меблі для закладів готельних і навчальних типів. Щодо м'яких меблів, то їх виробляють в Україні значно менше. До них належать: м'які крісла, дивани, пуфи тощо. Найбільш престижними виробниками меблів $\epsilon$ ті, які спеціалізуються на столярних виробах з рідкісних порід деревини, наприклад, червоного дерева.

На сьогодні меблеві фабрики оснащуються найновішим автоматизованим і механізованим вітчизняним i закордонним обладнанням, але це не виключає впливу шкідливих і небезпечних виробничих чинників на здоров'я і життя працівників меблевої фабрики. Особливо це стосується цехів механічного оброблення деревини, які найбільше насичені верстатним обладнанням і належать до найнебезпечніших у меблевому виробництві. Несприятливі умови праці властиві цехам, де відбувається оброблення деревини хімічними засобами різного призначення, а також дільниці з високим рівнем запиленості та шуму.

Основна діяльність верстатника у Командитному товаристві "Радивилівська меблева фабрика" пов'язана 3 операціями 3 оброблення деревини, виконуваними вручну і за допомогою різних інструментів. Верстатник виконує більш складну і тонку роботу, ніж тесля. Рівень його кваліфікації визначається розрядом, найвищий - шостий. Найпростіші роботи виконують верстатники 2-3-го розрядів. Верстатники 4-го розряду виготовляють і збирають предмети прямокутної форми. Верстатники 6-го розряду виготовляють, встановлюють і реставрують особливо складні фігурні і лекальні поручні, плінтуси, лиштву, виготовляють меблі.

До основних обов'язків верстатника належать:

- виготовлення і ремонт простого будівельного інвентарю;

- складні теслярські, загальнобудівельні й опалубні роботи;

- оброблення деревини електрифікованим інструментом i вручну;

- складні столярні роботи;

- виготовлення та встановлення столярних виробів.

У столярному цеху КТ "Радивилівська меблева фабрика" виготовляють: плінтуси, вагонку, лиштву, дошку для підлоги, перила, дерев'яні балясини, сходи, рами, двері (міжкімнатні, вхідні, вітальні, коридорні, сходові, кухонні, балконні, горищні), труни, вікна, євровікна (вікна зі склопакетом - дерев'яні, деревопластикові) тощо.

Недоліком професії $є$ високий рівень шуму в приміщеннях, дерев'яна стружка і пил, сильні запахи обробних розчинів (лаки, віск, фарби, клеї тощо), а також травмонебезпечне обладнання та інструмент.

Враховуючи наявність шкідливості і небезпеки на робочому місці верстатника, для уникнення випадків виробничого травматизму та професійних захворювань, передбачено випадки, коли верстатника не можна допускати до виконання роботи, а саме: 3 появою на роботі у стані алкогольного чи наркотичного сп'яніння; за відсутності спецодягу, спецвзуття та інших засобів індивідуального захисту відповідно до чинних норм i правил охорони праці; у разі хворобливого стану; у разі порушення правил, норм та інструкцій з охорони праці. Верстатник є підлеглим виконробу ділянки, а в процесі роботи - бригадиру і повинен виконувати тільки ту роботу, яка йому доручена.
Робітник повинен бути ознайомлений з небезпечними і шкідливими виробничими чинниками, що діють на працівника (небезпека одержання травм, отруєння, пожежі). Верстатнику видається спецодяг, спецвзуття та інші засоби індивідуального захисту відповідно до Типових галузевих норм: костюм віскозно-лавсановий, фартух бавовняний, рукавиці комбіновані.

Верстатник повинен користуватися додатковими засобами індивідуального захисту після інструктажу: окулярами під час заточування інструмента; респіратором та брезентовими рукавицями під час приготування антисептиків на органічних розчинниках; протишумовими навушниками - за наявності шуму.

Роботу ручним механізованим інструментом, а також стропування і розстропування матеріалів, що піднімаються вантажопідйомними механізмами, може виконувати тільки верстатник, який пройшов навчання і має відповідне посвідчення. До роботи на деревообробних верстатах допускається верстатник, який пройшов навчання за спеціальною програмою і стажування та має посвідчення на право роботи на верстаті.

Процес роботи верстатника складається з декількох етапів. Спочатку дерево потрібно ретельно підготувати до роботи: висушити, розпиляти полотна, відшліфувати. Потім відбувається розкрій i примірка деталей майбутнього виробу. На цьому етапі свердлять потрібні отвори, видовбують пази і т.ін. Далі виріб монтується за допомогою монтажних засобів або клею і, за потреби, покривається фарбою або лаком.

У своїй роботі верстатник застосовує різні техніки деревооброблення: розпилювання, стругання, виточування, склеювання, різьблення, застосовуючи для цього різноманітні інструменти: рубанок, лобзик, пила, сокира, стамеска, шпунтубель, ерунок, галтельнік.

Проте для шульг у цьому плані існує проблема, яка стосується механічного обладнання за типом фрезерних верстатів, пил тощо, яке виробляється тільки для праворуких і його використання шульгами без повноцінного контролю правою рукою може стати причиною не тільки поломки обладнання, але і нещасних випадків. Ліворукі працівники часто використовують електроінструмент, передбачений для праворуких, що несе високу загрозу одержання травми (зокрема, і втрату пальців або кінцівок). Багато електроінструментів і верстатів, що використовуються в столярній справі, дуже гучні, що може спричиняти приглухуватість. Вдихання тонкої суспензії тирси без респіратора здатне спричиняти різні захворювання дихальних шляхів. Однак, дотримання правил техніки безпеки та виробничої санітарії дають змогу уникнути більшості перерахованих проблем зі здоров'ям.

Проте, для забезпечення безпеки праці верстатниківшульг, важливим є саме правильна організація робочого місця, відповідно до його фізіологічних особливостей та потреб.

Основними складниками робочого місця є:

1) основне технологічне обладнання: верстати, станки, агрегати, автоматизовані лінії тощо;

2) допоміжне обладнання: засоби підіймання та транспортування, стенди тощо;

3) технологічне оснащення: пристосування, інструмент, технічна документація;

4) оснащення організаційного призначення: виробничі меблі, пристосування для зберігання інструменту та 
документації, засоби зв'язку, освітлення, вентиляції, засоби $з$ догляду за обладнанням та інструментом, предмети виробничого інтер'єру, засоби техніки безпеки та виробничої санітарії.

Для правильної організації робочого місця важливо розглядати його як систему, спрямовану на виконання виробничих функцій, що передбачає залучення до неї робітника, його особливостей і потреб, а також комунікативних зв'язків, як усних (спілкування), так і письмових (посадові інструкції). Максимальна кількість включених чинників у поняття "робоче місце" дає змогу повніше врахувати чинники, що впливають на ефективність та безпеку праці.

Важливим та першочерговим кроком під час організації робочого місця є планування, що передбачає раціональне розміщення робочих місць на виробничій площі та доцільне просторове розміщення в горизонтальній та вертикальній площинах у межах робочого місця всіх елементів оснащення, необхідних для виконання виробничого завдання.

До основних завдань планування робочих місць належать:

- створення ергономічних та безпечних умов праці;

- оптимальне використання виробничих площ;

- удосконалення використання робочого часу виконавців способом усунення зайвих рухів, ходіння, впровадження системи з п'яти кроків (сортуй, дотримуйся порядку, утримуй в чистоті, стандартизуй, удосконалюй).

Планування робочого місця можна поділити на внутрішне і зовнішне. Зовнішне планування полягає у встановленні його розміщення щодо суміжних робочих місць у виробничому підрозділі, робочого місця керівника, проходів, переходів, проїздів тощо. Внутрішне планування доцільно здійснювати відразу для усіх робочих місць, що входять у підрозділ.

Під час виконання зовнішнього планування необхідно досягнути таких результатів:

- ощадливого використання виробничих площ;

- раціонального взаємозв'язку між робочими місцями;

- скорочення відстаней переходів та транспортування;

- ізолювання робочих місць зі шкідливими і небезпечними умовами праці;

- забезпечення безпеки та гігієни праці відповідно до чинних вимог.

Внутрішнє планування робочих місць передбачає розташування на його площі усіх необхідних для виконання виробничого завдання предметів оснащення, а також їх раціональне компонування між собою та між ними і робітником.

Під час виконання внутрішнього планування важливо виконати такі завдання:

- забезпечити найменші витрати робочого часу на виконання робіт, що закріплені за цим робочим місцем;

- мінімізувати фізіологічні зусилля та нервово-психічну напруженість робітника;

- забезпечити зручність та ергономічність виконання виробничих рухів;

- забезпечити доступність для огляду в активній робочій зоні усіх частин обладнання, механізмів та приладів;

- оптимізувати маршрути переміщення робітника на своєму робочому місці;

- забезпечення ергономічності робочої пози робітника;

- створення безпечних і нешкідливих умов праці.

Складовою частиною виробничого процесу, спрямованою на забезпечення безперервного та ефективного функціонування робочого місця, $є$ його обслуговування. Організація обслуговування робочого місця передбачає визначення системи взаємодії робочого місця $\mathrm{i}$ робітника, що задіяний на ньому, з іншими робітниками, які зобов'язані забезпечити його безперервну та ефективну роботу.

Об'єктами обслуговування на робочому місці є засоби, предмети та суб'єкти праці. Під час облаштування робочого місця робітника-шульги важливо, щоб об'єкти обслуговування розташовувалися у порядку, зручному для нього і були пристосовані для працівників цієї категорії. Вже на етапі проектування нової або модернізації наявної техніки особливо важливо враховувати можливості і особливості людей, які будуть її використовувати. Вирішуючи задачі такого типу, необхідно узгоджувати між собою окремі рекомендації психології, фізіології, гігієни праці, соціальної психології та пов'язувати їх в єдину систему вимог до того чи іншого виду трудової діяльності людини.

Отже, для грунтовного вирішення проблеми створення ергономічного робочого місця верстатника-шульги, або й створення універсального робочого місця, надалі планується методом спостереження: визначити тип робочого місця; скласти перелік засобів праці, які застосовуються на цьому робочому місці і поділити їх на основні і допоміжні; скласти перелік органів керування, після чого поділити їх на групи (ручного керування, керування ногами, постійного, періодичного чи епізодичного керування); за технічною документацією визначити перелік технологічного та організаційного оснащення на робочому місці; виявити моторні та сенсорні зони активності і виділити головні 3 них, а також постійні, періодичні та епізодичні; скласти перелік ергономічних параметрів робочого місця для подальшого їх аналізу; виявити вплив розташування робочого місця на характер робочих рухів, робочу позу, визначити ступінь їх раціональності; визначити основну робочу позу методом вимірювання основного та допоміжного обладнання; оцінити висоту робочої поверхні, досяжність органів керування, зручність користування засобами відображення інформації, розмірами простору для ніг працюючого.

Після цього передбачається складання ескізу робочого місця (вигляд зверху, у профіль та спереду) з відображенням на ньому елементів робочого місця та параметрів, які необхідно оцінити. За виміряними параметрами робочого місця необхідно зробити креслення в певному масштабі, яке дасть змогу оцінити ступінь відповідності параметрів робочого місця антропометричним даним, а також фізіологічним можливостям працівників-шульг чи праворуких. На основі виконаного аналізу можна одержати картину наявних незручностей та визначити способи їх усунення.

Висновки. Варто зазначити, що коли трапляється нещасний випадок на виробництві, і на меблевій фабриці зокрема, то ніхто не звертає увагу на те, чи працівник ліворукий чи праворукий, такої статистики в Україні не ведуть. Однією 3 основних причин травматизму верстатників є неорганізоване робоче місце.

Тому для покращення умов праці верстатника-шульги необхідно дотримуватися таких основних рекомендацій. 1) Під час прийому на роботу шульги роботодавець повинен гарантувати забезпечення йому безпечних умов праці (придбання необхідного обладнання), в ін- 
шому випадку не приймати людей з ведучою лівою рукою для роботи на обладнанні для праворуких, для зниження ризику виникнення небезпечних ситуацій та загрози для життя і здоров'я не тільки самого працівника, а й оточення. 2) Велике значення має розташування та облаштування робочого місця, наприклад, для ліворуких робітників необхідно планувати виробниче освітлення так, щоб світло падало 3 правого боку. 3) Важливим $€$ правильне розташування всіх засобів праці та інструментів на робочому місці. Необхідним $є$ оснащення робітника інструментом, передбаченим для роботи ліворукими працівниками.

Оскільки технологічні процеси, оснащення та інструмент постійно удосконалюються, є потреба у грунтовному вивченні проблеми створення умов праці для ліворуких працівників відповідно до їхніх фізіологічних можливостей для захисту життя та здоров'я таких працівників. Для цього потрібно із застосуванням ергономічних методів досліджень провести комплексний аналіз робочих місць, де існує імовірність травмування робітників-шульг.

\section{References}

1. Bezrukikh, M., Efimova, S., \& Kruglov, B. (1995). Pochemu uchitsia trudno? Moscow: Semia i shkola, 208 p. [In Russian].

2. Chris McManus. (2003). Right-hand, Left-hand. Retrieved from: https://www.righthandlefthand.com/
3. Chuprykov, A. P., Hnatiuk, R., \& Chuprykova, M. (2011). Asymetriia mozku ta livorukist. Kyiv: KMM, pp. 94-99. [In Ukrainian].

4. Gebel, V. K., \& Glekler, M. (1996). Rebenok. Ot mladenchestva $k$ sovershennoletiiu. Moscow: Enigma, pp. 423-430. [In Russian].

5. Hurniak, I. H., \& Shevchenko, H. S. (2008). Analiz diialnosti pidpryiemstv meblevoi ta derevoobrobnoi promyslovosti v Ukraini. Scientific Bulletin of UNFU, 18(2), 216-225. [In Ukrainian].

6. Konventsiia pro prava osib z invalidnistiu (Konventsiia pro prava invalidiv). Redaktsiia vid 06.07.2016 roku. Retrieved from: https://zakon.rada.gov.ua/laws/show/995_g71. [In Ukrainian].

7. Kotovych, Z. A., \& Stanislavchuk, O. V. (2018). Pratsevlashtuvannia osib z invalidnistiu v konteksti sotsialnoi ta ekonomichnoi polityky Ukrainy. Problemy ta perspektyvy rozvytku systemy bezpeky zhyttiediialnosti: zbirnyk naukovykh prats KhIII Mizhnarodnoi naukovo-praktychnoi konferentsii molodykh vchenykh, kursantiv ta studentiv, Lviv. (pp. 297-298). [In Ukrainian].

8. Kutepova, I. (2002). Levsha v mire pravorukikh. Doshkolnoe vospitanie, 4, 64-69. [In Russian].

9. Levshi - samoe mnogochislennoe "menshinstvo" planety. Retrieved from: https://habr.com/post/398119/. [In Russian].

10. Proekt "Levsha - eto khorosho ili plokho?" Retrieved from: https://nsportal.ru/shkola/estestvoznanie/library/proekt-levsha-etokhorosho-ili-plokho. [In Russian].

11. Shkarban, L. V. (2016). Formuvannia hotovnosti vchyteliv pochatkovoi shkoly do roboty z livorukymy ditmy. Young Scientist, 5(32), 401-405. [In Ukrainian].

12. Strilchuk, R. M., Kryvoviaziuk, I. V., \& Kryvoviaziuk, B. I. (2019). Ekonomichna diahnostyka diialnosti promyslovoho pidpryiemstva: teoriia, metodyka ta praktyka realizatsii. (Ser. Economic sciences). Scientific Bulletin of Kherson State University, 33, 130-137. https://doi.org/10.32999/ksu2307-8030/2019-33-26

\section{O. V. Stanislavchuk, V. M. Marych, N. S. Kazmiruk}

Lviv State University of Life Safety, Lviv, Ukraine

\section{ACTUAL ISSUES FOR PROVIDING LABOR SAFETY OF LEFT-HANDED WORKERS}

The problem of creating safe and harmless working conditions has always worried mankind. When analyzing actual problems only ways to solve the problem of rational job placement and creating safe and harmless working conditions for workers with disabilities and special needs were found. However, for the last few decades, the number of left-handed people has increased by 3-4 times in the world due to the cessation of the retraining left-handed people. As a result of the analysis of the literary sources it is revealed that the issue of creating safe and harmless labour conditions for this category of workers there is almost no research, especially in Ukraine. The article contains the analysis of problems that arise when working with left-handed workers. While researching the issue of adaptation left-handed workers in different industries such research methods as monographs, ergatic, peer review, statistical analysis are used. Studies were also conducted on the example of a workplace joiner at the Radivilovska Furniture Factory Command Society, as the furniture industry in Ukraine has acquired distribution, and therefore the profession of carpenter is in demand. Taking into account that $70 \%$ of jobs, equipment and the tools is designed for left-handed workers, there is a high risk of not only equipment failure, but also occupational injuries. Given such situation, the employee becomes acquiring the necessary skills by right-hand. However, if there is a need to act in an emergency mode, if there is lack of time, such employee automatically engages the leading hand, which leads to erroneous movements, and undesirable consequences. Therefore, today it is extremely important to carry out further research on the left-handed workers' performing problems not only the profession of joiner at furniture factories, but also other professions, in which work is related to the specifics of the equipment - for right-handed, and in some cases, left-handed, workers. As a result of the conducted research the list of basic recommendations is formed which should be followed in case of employment a lefthanded worker as a carpenter.

Keywords: left-handed worker; right-handed worker; working conditions; workplace; tool; occupational injuries. 